\title{
Hill の安定条件の粒状体への適用性について
}

\author{
岸野佑次 ${ }^{1} \cdot$ 武 建勳 ${ }^{2}$ \\ ${ }^{1}$ 正会員 工博 東北大学教授 大学院工学研究科土木工学専攻（テ980-8579 仙台市青葉区荒巻字青葉06） \\ 2 学生会員 工修 東北大学大学院博士後期課程 工学研究科土木工学専攻
}

\begin{abstract}
本文においては，まず, Hill の安定条件の検討を行うために用いた粒状要素法による応力制御要素試験 プログラムのアルゴリズムについて示した。つぎに, Hillの安定条件の理論的背景を明らかにするために, 動的仮想仕事の原理に基づく安定条件式の誘導とその考察を行った. 粒状体への適用性の具体的な検討は, 側圧一定せん断載荷シミュレーションで得られた 2 種の中途データを対象とする詳細な応力プローブ試験 シミュレーション結果に基づいて行い, 塑性論における流動則とは微妙なずれが生じること，ならびに安 定な硬化段階では，このずれのために Hill の安定条件が満たされることを見出した．さらに，粒状体の安 定性を詳細に論じるためには，構成則に増分非線形性を取り入れる必要性もあることなどを考察した。
\end{abstract}

Key Words : granular materials, Hill's conditon of stability, granular element method, stress-probe simulation, incremental non-linearity

\section{1.まえがき}

近年, 粒状体の力学的安定性の問題について種々 の議論がなされている，とくに，応力ひずみ関係に おけるピーク以前の硬化過程において Hill の安定条 件1), 2) が満たされるかどうか，また，満たされないと すれば実際に不家:定現象が生じるかどうかが大きな 問題となっている. $\mathrm{Lade}^{3)}$ は砂の応力制御三軸排水 試験結果を示し, 塑性挙動は非関連流動則に従うと 認められ, Hill の安定条件に反した結果が観察され たにも拘わらず，不安定現象は認められなかったと 述べた。一方, Drucker ${ }^{4}$ は非関連流動則が成立する とすれば必ず不安定になることを数值解析例によっ て示すとともに，塑性挙動の実際が明らかでないと すれば，敢えて非関連流動則を用いる必要はないの ではないかと述べた。このような議論に実証的な方 法で決着をつけるためには, より詳細かつ精密な地 盤材料の実験を実施する必要があるであろう.

一方, 粒状体の非弾性挙動を知るための一つの有 カなアプローチとして，離散的粒状体モデルによる シミュレーション解析が行われている。 Bardet $^{5)}$ は Cundall $^{6)}$ の提案した個別要素法を用いて応力プロー ブ試験シミュレーションを実施し, 粒状体モデルの 塑性挙動を通常の非関連流動則により説明できない という証拠は見出し得なかったとの結論を得た。し かし Bardet のシミュレーション解析においては, 応 力制御プローブか所期の設定通りに行われておらず,
例えば，弾塑性応答に基づいて安定性の詳細な検討 を行うことなどは困難であると考えられる，Bardet が精度良く要素試験を行えなかった理由は, 個別要 素法の応力制御アルゴリズムに起因すると思われる.

個別要素法と同様の離散的解析手法として, 著者 の一人は粒状要素法 ${ }^{7}$ を提案した。この方法は主と して粒状体の静的な性質を精度良く調べることを目 的として開発されたものであり，種々の応用が試み られている。 とくに, 応力プローブ試験への応用例 としては増分非線形性の考察息や，上述の Bardet 論文に対応したシミュレーション解析 ${ }^{9)}{ }^{10)}$ が行われ ている.これらの解析結果は粒状要素法が精度の良 い応力プローブ試験を可能にすることを示している。 しかし, これらの論文における応力プローブ方向は 限定されたものであり, 増分非線形性や安定条件な どについて明確な結論を得るまでには至っていない。

以上のような背景の下に, 本研究においては, 粒 状要素法を用いた詳細なシミュレーション解析を行 い, 古典的弾塑性理論が粒状体の真の非弾性挙動を 正確に表現し得るかという問題および Hill の安定条 件が粒状体の安定性評価にも有効であるかという問 題について考察する。 なお, 本文においては, 実際 の検討結果を示す前に, 本研究で用いた要素試験シ ミュレーションのアルゴリズムを提示する．また， Hill の安定条件の意味を明らかにするために, Hill とは異なる方法で安定条件の誘導を行うとともに, 安定条件が成立するための前提条件を明らかにする。 


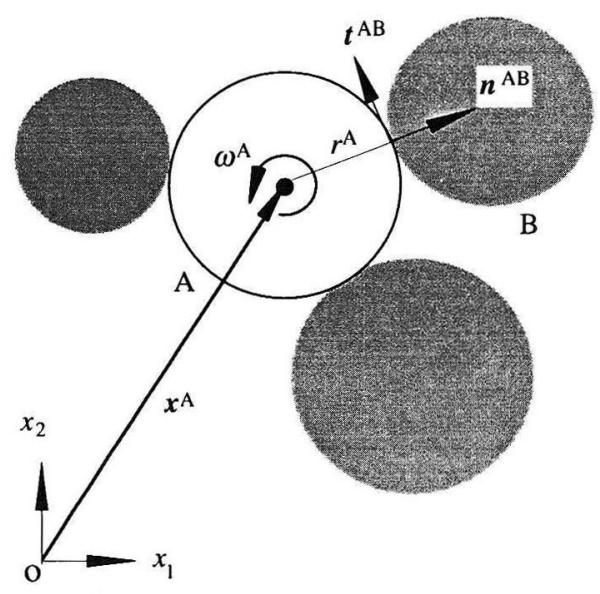

図-1 粒状供試体モデル内の典型的な粒子とその接触粒子

\section{2. 要素試験を想定した粒状要素解析法}

岸野 ${ }^{7)}$ によって提案された粒状要素法の解析アル ゴリズムは初期のものから種々変遷しているので, ここでは，本論文で Hill の安定条件の適用性を調べ るために行った粒状供試体モデルの要素試験シミュ レーションに用いた解析アルゴリズムを示す.

\section{(1) 粒子移動と接触力}

図-1 に粒状体モデル中の典型的な粒子とその接触 粒子を示す. 粒子 A, B の半径を $r^{\mathrm{A}}, r^{\mathrm{B}}$, 重心の位置 ベクトルを $x^{\mathrm{A}}, x^{\mathrm{B}}$ とする。このとき, 両粒子の接 触点における粒子 $\mathrm{A}$ 側の単位法線ベクトルは

$$
n^{\mathrm{AB}}=\left(x^{\mathrm{B}}-x^{\mathrm{A}}\right) / d^{\mathrm{AB}}
$$

と表すことができる。ここに， $d^{\mathrm{AB}}=\left|x^{\mathrm{B}}-x^{\mathrm{A}}\right|$ は粒 子重心間距離である。 また，この接触点における粒 子 $\mathrm{A}$ 側の単位接線ベクトル $\boldsymbol{t}^{\mathrm{AB}}$ を $\boldsymbol{n}^{\mathrm{AB}}$ を反時計回 りに $90^{\circ}$ 回転したベクトルとして定義する.すなわ ち, $t^{\mathrm{AB}}$ の成分を次式で与える.

$$
t_{1}^{\mathrm{AB}}=-n_{2}^{\mathrm{AB}}, t_{2}^{\mathrm{AB}}=n_{1}^{\mathrm{AB}}
$$

つぎに，時間ステップ $\Delta t$ における粒子 $\mathrm{A}, \mathrm{B}$ の並 進移動の増分を $\Delta x^{\mathrm{A}}, \Delta x^{\mathrm{B}}$, 回転の増分を $\Delta \omega^{\mathrm{A}}, \Delta \omega^{\mathrm{B}}$ と表す。これらの 2 粒子の移動を基に, 粒子間の相 対変位増分は次式のように表すことができる.

$$
\left.\begin{array}{l}
\Delta u_{n}^{\mathrm{AB}}=\left(\Delta x^{\mathrm{A}}-\Delta x^{\mathrm{B}}\right) \cdot n^{\mathrm{AB}} \\
\Delta u_{t}^{\mathrm{AB}}=\left(\Delta x^{\mathrm{A}}-\Delta x^{\mathrm{B}}\right) \cdot t^{\mathrm{AB}}+r^{\mathrm{A}} \Delta \omega^{\mathrm{A}}+r^{\mathrm{B}} \Delta \omega^{\mathrm{B}}
\end{array}\right\}
$$

一方, A 粒子から B 粒子に作用する接触力の成分 を $f_{n}^{\mathrm{AB}}, f_{t}^{\mathrm{AB}}$ と表す. 相対変位および接触力の法線 方向成分は圧縮が正，接線方向成分は相手粒子の右

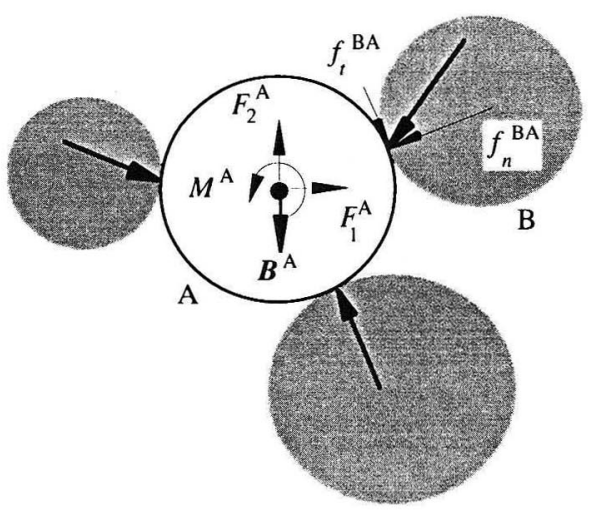

図-2 粒子に作用する力

ずれが正である。いま，図-2 に示すように，粒子A が物体力 $B^{\mathrm{A}}$ の作用の下に静的平衡状態にあるとす ると, 粒子 A から隣接粒子に作用する接触力の合力

$$
\boldsymbol{F}^{\mathrm{A}}=\Sigma_{\mathrm{B}}\left(f_{n}^{\mathrm{AB}} \boldsymbol{n}^{\mathrm{AB}}+f_{t}^{\mathrm{AB}} \boldsymbol{t}^{\mathrm{AB}}\right)
$$

は $\boldsymbol{F}^{\mathrm{A}}=\boldsymbol{B}^{\mathrm{A}}$ を満たす。ここに， $\boldsymbol{\Sigma}_{\mathrm{B}}$ は粒子 $\mathrm{A}$ に接 触している全粒子についての和を表す。また, 粒子 A から隣接粒子に作用する接触力のモーメント

$$
M^{\mathrm{A}}=r^{\mathrm{A}} \Sigma_{\mathrm{B}} f_{i}^{\mathrm{AB}}
$$

（反時計廻り正）は $M^{\mathrm{A}}=0$ を満たす.

2 粒子 $\mathrm{A}, \mathrm{B}$ の重心間距離について

$$
d^{\mathrm{AB}}<r^{\mathrm{A}}+r^{\mathrm{B}}
$$

が満たされると A, B は互いに重なり合う。粒子を 弾性体とした場合, 重心間距離と接触力とは理論的 には非線形な式で関係づけられるが，ここではこれ を線形化して簡易的にとり扱うこととする。すなわ ち接触力法線方向成分は, 法線方向バネ定数を $k_{n}$ として, 次式で与えられる.

$$
f_{n}^{\mathrm{AB}}=k_{n}\left(r^{\mathrm{A}}+r^{\mathrm{B}}-d^{\mathrm{AB}}\right)
$$

上式に対する増分型の表式は，式（3）で定義した 相対変位增分を用いて次式で与えられる。

$$
\Delta f_{n}^{\mathrm{AB}}=k_{n} \Delta u_{n}^{\mathrm{AB}}
$$

一方，接線方向成分については式（7）のような 表式が存在しない。これは, 粒子間にすべりが発生 するので, 各時点における接触力接線方向成分が過 去の履歴の影響を受けるためである。したがって， 接触力の接線方向成分 $f_{t}^{\mathrm{AB}}$ は, 2 粒子 $\mathrm{A}, \mathrm{B}$ が接し 始めた時点以降, 解析各ステップで生じた増分值の 和として算定されることになる．接触力増分の接線 方向成分は, すべりが発生しない限り, 接線方向バ ネ定数を $k_{t}$ として, 次式で与えられる.

$$
\Delta f_{t}^{\mathrm{AB}}=k_{t} \Delta u_{t}^{\mathrm{AB}}
$$

逐次解析過程において，もし 2 粒子 A，B の重心 


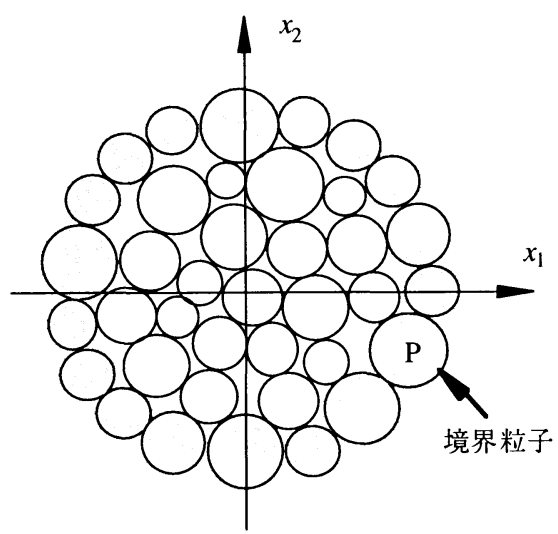

図-3 粒状供試体モデル概念図

間距離が式（6）を満たさなくなったときには，接 触力の法線方向成分および接線方向成分を強制的に 零と置くこととする。 また, 粒子間接触力の接線成 分が Coulomb の摩擦則で定まる限界值を超えるこ とがないように，次式の限界值を超えた場合には， 強制的にこの限界值に戻す修正を行うこととする。

$$
f_{t}^{\prime \mathrm{AB}}=\frac{f_{t}^{\mathrm{AB}}}{\left|f_{t}^{\mathrm{AB}}\right|}\left(c+f_{n}^{\mathrm{AB}} \tan \phi\right)
$$

ここに, $\phi$ は粒子間摩擦角, $c$ は粒子間粘着力である.

\section{（2）境界粒子の制御と応力}

以下，図-3に示すような 2 次元円粒子集合を粒状 供試体モデルとする要素試験を想定して剛性行列を 構成する，領域境界の形状は任意であるが，領域の 幾何学形状の異方性が要素試験結果に影響を及ぼさ ないようにするには円形領域を用いることが望まし いと考えられる。粒状供試体モデル周辺に配置され た円粒子は境界粒子と称される。境界粒子は粒状供 試体モデルの応力やひずみを制御するために用いら れ，境界粒子同士の相互作用は意味をもたない。

粒状供試体モデルの境界の移動を常に巨視的な変 形勾配に適合したものとするために各境界粒子には 特別な移動を強制することとする，すなわち，境界 粒子 P の重心の位置座標は常に次式で与えられる位 置に移動するような制御を行う。

$$
\boldsymbol{x}^{\mathrm{P}}=\boldsymbol{T} \cdot \boldsymbol{X}^{\mathrm{P}}
$$

ここに， $x^{\mathrm{P}}$ および $\boldsymbol{X}^{\mathrm{P}}$ は，それぞれ，境界粒子重 心の現在および基準状態における重心の位置座標,

$\boldsymbol{T}$ は粒状供試体モデルに与える変形勾配である。な お，境界粒子の回転は拘束する。また領域全体の回 転はないものとし，Tは対称とする．

ここで, 有限変形を考慮し, 変形勾配 $\boldsymbol{T}$ にエネル

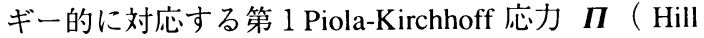
の論文 ${ }^{1), 21}$ における nominal stress）の算定方法につ いて説明する。 Пの成分 $\Pi_{i j}$ は，基準状態において 法線が $x_{i}$ 方向を向いていた単位面素に対応する現 在の面素に作用している応力べクトルの第 $j$ 成分を 与える。この応力は, 以下のように, 粒子の仮想変 位增分に対して領域表面に作用する接触力と応力の する仕事の増分を等值することにより与えられる。

まず，粒状供試体モデルの境界粒子 P から内部 粒子に作用する接触力の合力は

$$
\boldsymbol{F}^{\mathrm{P}}=\Sigma_{\mathrm{l}}\left(f_{n}^{\mathrm{Pl}} n^{\mathrm{PI}}+f_{t}^{\mathrm{Pl}} \boldsymbol{t}^{\mathrm{Pl}}\right)
$$

である。ここに， $\Sigma_{\mathrm{I}}$ は各境界粒子に接している内 部粒子についての和を表す。つぎに，境界粒子の変 位増分は, 変形勾配の増分を $\Delta \boldsymbol{T}$ とすれば, 式

（11）より次式で与えられる.

$$
\Delta \boldsymbol{x}^{\mathrm{P}}=\Delta \boldsymbol{T} \cdot \boldsymbol{X}^{\mathrm{P}} \quad\left(\text { または, } \Delta x_{i}^{\mathrm{P}}=\Delta T_{i j} X_{j}^{\mathrm{P}}\right)
$$

ここで, 領域表面に作用する接触力のする仕事の増 分と応力のする仕事の増分を次式のように等置する.

$$
\Delta W=-\Sigma_{\mathrm{P}} F^{\mathrm{P}} \cdot \Delta \boldsymbol{x}^{\mathrm{P}}=\Pi: \Delta \boldsymbol{T} A_{0}
$$

ここに， $\Sigma_{\mathrm{P}}$ は全境界粒子に関する和を表し， $A_{0}$ は 基準状態における境界粒子重心を結ぶ多角形の面積, $\Pi: \Delta \boldsymbol{T}$ は複内積 $\Pi_{i j} \Delta T_{j i}$ を意味する。式 (12)， （14）より，次式が成立する。

$$
\boldsymbol{\Pi}=-\Sigma_{\mathrm{P}} \Sigma_{\mathrm{I}} \boldsymbol{X}^{\mathrm{P}}\left(f_{n}^{\mathrm{PI}} n^{\mathrm{PI}}+f_{t}^{\mathrm{PI}} t^{\mathrm{PI}}\right) / A_{0}
$$

なお, Cauchy 応力 ( Hill の論文1).2) における true stress ）を必要とする場合は，式（15）における境 界粒子重心の位置座標ベクトル $\boldsymbol{X}^{\mathrm{P}}$ を現在の位置座 標ベクトル $\boldsymbol{x}^{\mathrm{P}}$ に, 面積 $A_{0}$ を現在の面積 $A$ に置き 換えればよい。

\section{(3) 剛性行列の構成}

図-1において，A 粒子の並行移動増分と粒子回転 増分よりなる変位増分ベクトルを

$$
\Delta U^{\mathrm{A}}=\left(\Delta x_{1}^{\mathrm{A}}, \Delta x_{2}^{\mathrm{A}}, r^{\mathrm{A}} \Delta \omega^{\mathrm{A}}\right)^{\mathrm{t}}
$$

と置く。また， A 粒子重心に付加する力とモーメン トの増分を表す付加力増分べクトルを

$$
\Delta F^{\mathrm{A}}=\left(\Delta F_{1}^{\mathrm{A}}, \Delta F_{2}^{\mathrm{A}}, \Delta M^{\mathrm{A}} / r^{A}\right)^{\mathrm{t}}
$$

と表す。A 粒子の移動 $\Delta U^{\mathrm{A}}$ ，ならびに $\Delta U^{\mathrm{B}}$ などの $\mathrm{A}$ 粒子に隣接する粒子の移動が生じたときに，A 粒子に付加すべき付加力増分べクトルは，式（3）,

(4)，(5)，(8），(9）ょり, 次式のように置くこ とができる。

$$
\Delta F^{\mathrm{A}}=K^{A} \Delta U^{\mathrm{A}}-\Sigma_{\mathrm{B}} K^{\prime \mathrm{AB}} \Delta U^{\mathrm{B}}
$$


ここに，

$$
\begin{aligned}
& K^{A}=\Sigma_{\mathrm{B}} K^{\mathrm{AB}} \\
& K^{\mathrm{AB}}=\left(\begin{array}{c}
k_{n}\left(n_{1}^{\mathrm{AB}}\right)^{2}+k_{t}\left(n_{2}^{\mathrm{AB}}\right)^{2} \\
\left(k_{n}-k_{t}\right) n_{1}^{\mathrm{AB}} n_{2}^{\mathrm{AB}} \\
-k_{t} n_{2}^{\mathrm{AB}}
\end{array}\right.
\end{aligned}
$$

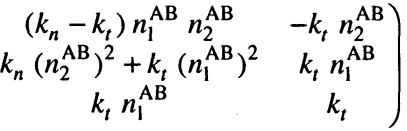

$$
\begin{aligned}
& K^{\prime \mathrm{AB}}=\left(\begin{array}{c}
k_{n}\left(n_{1}^{\mathrm{AB}}\right)^{2}+k_{t}\left(n_{2}^{\mathrm{AB}}\right)^{2} \\
\left(k_{n}-k_{t}\right) n_{1}^{\mathrm{AB}} n_{2}^{\mathrm{AB}} \\
k_{t} n_{2}^{\mathrm{AB}}
\end{array}\right. \\
& \left.\begin{array}{cc}
\left(k_{n}-k_{t}\right) n_{1}^{\mathrm{AB}} n_{2}^{\mathrm{AB}} & k_{t} n_{2}^{\mathrm{AB}} \\
k_{n}\left(n_{2}^{\mathrm{AB}}\right)^{2}+k_{t}\left(n_{1}^{\mathrm{AB}}\right)^{2} & -k_{t} n_{1}^{\mathrm{AB}} \\
-k_{t} n_{1}^{\mathrm{AB}} & -k_{t}
\end{array}\right)
\end{aligned}
$$

であり, $K^{\mathrm{A}}$ を主要素剛性行列, $K^{\prime \mathrm{AB}}$ を従要素剛 性行列と称する。

粒状供試体モデル内の全接触点に関して以上の主 従の要素剛性行列を重ね合わせることにより, 境界 粒子も含めた全ての粒子の変位増分と回転增分を未 知数とした全体剛性行列が得られる。ところで, 境 界粒子の移動は式（11）に従って共通の変形勾配 3 成分に支配される。したがって, 粒状供試体モデル の移動の自由度は, 内部粒子の数を $n$ とするとき, $3(n+1)$ になる。また，式（15）を用いれば，応力 増分 3 成分は境界粒子付加力増分ベクトルにより表 すことができる，よって，境界粒子については，変 位増分ベクトルの代わりに変形勾配増分べクトル

$$
\Delta U^{\prime}=\left(\Delta T_{11}, \Delta T_{22}, 2 \Delta T_{12}\right)^{\mathrm{t}}
$$

付加力増分べクトルの代わりに応力増分ベクトル

$$
\Delta F^{\prime}=\left(\Delta \Pi_{11}, \Delta \Pi_{22}, \Delta\left(\Pi_{12}+\Pi_{21}\right) / 2\right)^{\mathrm{t}}
$$

を独立変数とする．さらに，全ての内部粒子の付加 力増分ベクトルを並べたベクトルを $\Delta F^{\prime \prime}$, 変位増分 ベクトルを並べたベクトルを $\Delta U^{\prime \prime}$ と置く．このと き, 粒状供試体モデルの剛性関係式は

$$
\Delta F=S \Delta U
$$

と与えられる.ここに，

$$
\Delta F=\left(\begin{array}{c}
\Delta F^{\prime} \\
\Delta F^{\prime \prime}
\end{array}\right) \quad \Delta U=\left(\begin{array}{c}
\Delta U^{\prime} \\
\Delta U^{\prime \prime}
\end{array}\right)
$$

である.

いま，全体剛性行列 $S$ を境界粒子および内部粒 子に対応する部分に分割し, 次式のように表す.

$$
S=\left(\begin{array}{ll}
S_{11} & S_{12} \\
S_{21} & S_{22}
\end{array}\right)
$$

ここに, $D=S_{11}$ は応力増分と変位勾配增分に対応
する $3 \times 3$ の小行列であり，式（8），(9），(13）， （15）により各成分は次式のように与えられる.

$$
\left.\begin{array}{l}
d_{11}=\Sigma_{\mathrm{P}} \Sigma_{\mathrm{l}} k_{11}^{\mathrm{Pl}} X_{1}^{2} / A_{0} \\
d_{22}=\Sigma_{\mathrm{P}} \Sigma_{\mathrm{l}} k_{22}^{\mathrm{Pl}} X_{2}^{2} / A_{0} \\
d_{12}=\Sigma_{\mathrm{P}} \Sigma_{\mathrm{l}} k_{12}^{\mathrm{Pl}} X_{1} X_{2} / A_{0} \\
d_{13}=\Sigma_{\mathrm{P}} \Sigma_{\mathrm{I}}\left(k_{11}^{\mathrm{PI}} X_{1} X_{2}+k_{12}^{\mathrm{PI}} X_{1}^{2}\right) / 2 A_{0} \\
d_{23}=\Sigma_{\mathrm{P}} \Sigma_{\mathrm{I}}\left(k_{12}^{\mathrm{PI}} X_{2}^{2}+k_{22}^{\mathrm{PI}} X_{1} X_{2}\right) / 2 A_{0} \\
d_{33}=\Sigma_{\mathrm{P}} \Sigma_{\mathrm{I}}\left(k_{11}^{\mathrm{Pl}} X_{2}^{2}+2 k_{12}^{\mathrm{PI}} X_{1} X_{2}+k_{22}^{\mathrm{Pl}} X_{1}^{2}\right) / 4 A_{0}
\end{array}\right\}
$$

ここに， $k_{i j}^{\mathrm{PI}}$ は式（20）により定義される行列の $i j$ 成分である，全体剛性行列は対称であり，次式が成 り立つ.

$$
S_{21}=S_{12}^{t}
$$

本研究における要素試験シミュレーションの境界 制御は全て応力制御であり，4.に述べるシミュレー ション解析は全て式（24）に基づいている.

なお，ひずみ制御による要素試験を行う場合には， 剛性関係式を以下のように変形すればよい，すなわ ち, 式（24）において既知量である変形勾配増分を 左辺へ, 未知量である応力増分を右辺に移すことに より，次式のような剛性関係を得る。

$$
\left(\begin{array}{c}
\Delta U^{\prime} \\
\Delta F^{\prime \prime}
\end{array}\right)=\left(\begin{array}{cc}
D^{-1} & -D^{-1} S_{12} \\
S_{21} D^{-1} & S_{22}-S_{21} D^{-1} S_{12}
\end{array}\right)\left(\begin{array}{c}
\Delta F^{\prime} \\
\Delta U^{\prime \prime}
\end{array}\right)
$$

以上のように，粒状要素法は境界制御を自由に行 うことができ，要素試験シミュレーションに適して いる。これに対して，個別要素法は応力制御を精度 良く行うことが困難なようである ${ }^{5), 10)}$.

\section{(4) 剛性関係式の簡易解法アルゴリズム}

要素試験シミュレーションの載荷過程においては, 接触力や全体剛性行列の改定を時々刻々行わなけれ ばならない。これに対応するため, 逐次反復解析法 を必要とする。ここでは, 応力制御要素試験シミュ レーションを想定した解析アルゴリズムについて説 明する. 図-4に応力目標值を設定した後の解析アル ゴリズムのフローチャートを示す.

まず, 逐次反復解析過程の一つのステップにおけ る応力目標値を $\bar{\Pi}_{11}, \bar{\Pi}_{22}, \bar{\Pi}_{12}$ と置き, この目標値と 実際に実現されている応力との差, 並びに, 各内部 粒子の接触力合力（式（4），(5））の不釣り合い 量を成分とするべクトルを次式のように定める.

$$
\begin{aligned}
& \Delta F=\left(\bar{\Pi}_{11}-\Pi_{11}, \bar{\Pi}_{22}-\Pi_{22}, \bar{\Pi}_{12}-\left(\Pi_{12}+\Pi_{21}\right) / 2,\right. \\
& \left.B_{1}^{\mathrm{Il}}-F_{1}^{\mathrm{Il}}, B_{2}^{\mathrm{Il}}-F_{2}^{\mathrm{Il}},-M^{\mathrm{Il}} / r^{\mathrm{Il}}, \cdots,-M^{\mathrm{In}} / r^{\mathrm{In}}\right)^{\mathrm{t}}
\end{aligned}
$$

ここに, Il In は内部粒子の番号である. 
逐次反復解析は, 式 (24) の左辺に上式の不釣り 合い量 $\Delta F$ を逐次代入することにより行う。これは 以下の考え方に基づいている，いま， $\Delta F$ で表され る現状の不釣り合い状態に対して，もし仮想的な外 カ $-\Delta F$ を補って考えると, 現状は仮想的な釣り合 い状態にあることになる。しかし，現実には仮想的 外力は作用しないので, 実際に $\Delta F$ を加えれば仮想 的外力が解消され, 実際の釣り合い状態が得られる ことになる，以上より，平衡状態を与える恋位増分 は次式で与えられる。

$$
\Delta U=S^{-1} \Delta F
$$

ところで，各粒子に $\Delta U$ に対応した接触力増分を 付加すると平衡条件は一旦満たされるが, 一般には 粒子間の接触・非接触の変化やすべりが発生するの で, 接触力の補正を行う必要がある. すなわち, 負 の接触力法線成分が生じたときは接触力を零とし, 接線成分については必要に応じて式（10）の補正を 行う。このとき新たな不釣り合い状態が生じるので, 剛性行列 $S$ の改定を行った上で式（32）の計算を繰 り返す必要がある。しかし， Sの改定およびその逆 行列の計算には多くの計算時間を要するので, 以下 のような簡易な計算方法を用いることとする。

まず， $S$ の改定に関しては, 粒子移動により粒子 同士の新たな接触・非接触の変化が生じない限り行 わないこととする。 また, 式（32）における剛性行 列 $S$ の逆行列の計算を簡略化するために, 反復計算 を前提とした便法を用いる。すなわち, 以下のよう に, 剛性行列 $S$ を構成する小行列の中, 従要素剛性 行列に対応する部分を無視して, 主要素剛性行列に 対応する部分だけを残す。

$$
S=\left(\begin{array}{cccc}
D & 0 & \cdot & 0 \\
0 & K^{11} & \cdot & 0 \\
\cdot & \cdot & \cdot & \cdot \\
0 & 0 & \cdot & K^{\ln }
\end{array}\right)
$$

ここに, $K^{\mathrm{li}}(i=1, \cdots, n)$ は各内部粒子について式 （19）で定義される $3 \times 3$ の主要素剛性行列である. $D や K^{\mathrm{li}}$ の逆行列は陽な形で求まり, $S$ の逆行列は これらの小行列の逆行列を並べたものとなる.

$$
S^{-1}=\left(\begin{array}{cccc}
D^{-1} & 0 & \cdot & 0 \\
0 & \left(K^{11}\right)^{-1} & \cdot & 0 \\
\cdot & \cdot & \cdot & \cdot \\
0 & 0 & \cdot & \left(K^{\mathrm{In}}\right)^{-1}
\end{array}\right)
$$

なお，行列 $K^{\mathrm{I} i}$ は特異になることがあり得るので, あらかじめ対角線上に粒子間バネ定数に比して十分 小さな量を加え, 特異性を排除することとする.

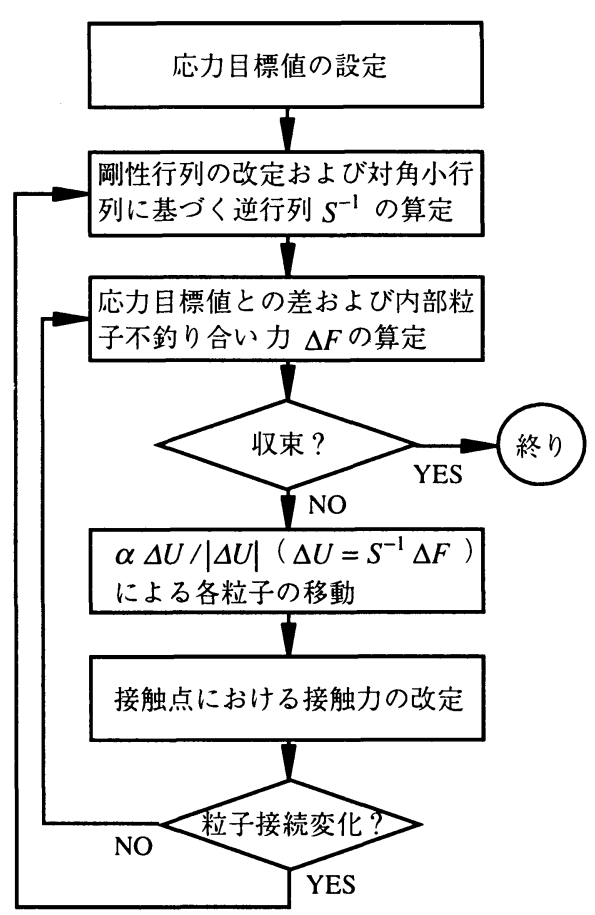

図-4 応力制御要素試験の解析アルゴリズム

式（34）ような簡易的逆行列を用いた逐次反復解 析法に類似の方法としてラーメン構造の古典的数值 解法であるモーメント分配法が挙げられる。この解 析法においては, 着目節点以外の節点を固定して, 不釣り合いモーメントを逐次解消して行く方法を用 いているが, 基本的考え方は上記の従要素剛性行列 を無視することに等価である．ただし，粒状要素法 ではモーメント分配法のように不釣り合い量の解消 を順序づけて行う方法はとらず, 全不釣り合い力を 式（32）に基づいて同時に解消する方法をとる.

つぎに，式（32）に基づいて算定される $\Delta U に$ 関 しては以下のような取り扱いを行うこととする。逐 次反復解析の各ステップで求まる $\Delta U$ は, 場合によっ ては, 粒子間に大きな相対変位や過度の重なり合い を生じさせ，非現実的な粒子移動や不安定な収束計 算の原因となる。これを避けるために，式（32）に 基づいて算定される移動量はその成分の比のみを利 用し, 絶対量については各逐次計算ステップにおけ る変位ベクトル $\Delta U$ のノルムを一定に保つように, $\Delta U$ の代わりに $\alpha \Delta U /|\Delta U|$ （ $\alpha$ は与える移動量の） ルムを表す正の定数）を用いる.

以上の逐次反復計算は, 次の応力の目標值を定め た新しい載荷ステップに移る前に, $|\Delta F|$ がある許容 誤差の範囲内に収まるまで繰り返すことになる。 


\section{3. 仮想仕事の原理によるHillの安定条件の誘導}

硬化状態におかれた材料が Hill の安定条件 ${ }^{1), 2)}$ 満たすべきかどうかについては従来より議論のある ところである ${ }^{3), 4)}$.ここでは, Hill の安定条件よりや や一般的な形の安定条件を動的仮想仕事の原理を用 いて誘導するとともに，Hill の安定条件の適用性に ついて考察を行うこととする.

いま，連続体が静的に安定した状態にあるとした 場合，この連続体は静的な平衡条件を满たしている。 しかし, 静的な平衡状態を動的な方程式において慣 性項等を無視して実現したものと考えるならば，不 安定現象を捉えるためには，動的な項を補って考え る必要がある，以下，動的な平衡条件を考えること とし，図-5に示すように，ある連続体の基準状態に おける領域を $V_{0}$, 境界を $S_{0}$, 密度を $\rho_{0}$ とする. 領域内の物質点をその点の基準状態の位置べクトル $X$ で表し, 時刻 $t$ をパラメータとする物質点の運動 を $\boldsymbol{x}=\boldsymbol{x}(\boldsymbol{X}, t)$, 変形勾配を $\boldsymbol{T}(\boldsymbol{X}, t)=\partial \boldsymbol{x}(\boldsymbol{X}, t) / \partial \boldsymbol{X}$ また は $T_{i j}=\partial x_{i} / \partial X_{j}$ と置く。また, この領域に作用する 外力として, 基準状態単位面積当たりの表面力を $\boldsymbol{t}_{0}$, 基準状態単位体積当たりの物体力を $\boldsymbol{b}_{0}$ で表す. さらに，領域内部の応力は第 1 Piola-Kirchhoff 応力 Пで表す。このとき, 時刻 $t$ におけるこの系の動的 平衡条件より次の仮想仕事の原理が成立する.

$$
\begin{aligned}
\int_{S_{0}} \boldsymbol{t}_{0} \cdot \delta \boldsymbol{x} d S_{0}+\int_{V_{0}}\left(\boldsymbol{b}_{0}-\rho_{0} \ddot{\boldsymbol{x}}\right) & \cdot \delta \boldsymbol{x} d V_{0} \\
& =\int_{V_{0}} \boldsymbol{\Pi}: \delta \boldsymbol{T} d V_{0}
\end{aligned}
$$

ここに, $\Pi: \delta T$ は $\Pi_{i j} \delta T_{j i}$ を表す。時刻 $\Delta t$ 後に $\Pi$ が $\Pi+\Delta \Pi, \ddot{x}$ が $\ddot{x}+\Delta \ddot{x} に な っ た と し ， b_{0}$ は一定と する。この状態に対する仮想仕事の原理は次式のよ うに表される。

$$
\begin{aligned}
\int_{S_{0}}\left(\boldsymbol{t}_{0}+\Delta \boldsymbol{t}_{0}\right) \cdot \delta \boldsymbol{x} d S_{0}+ & \int_{V_{0}}\left\{\boldsymbol{b}_{0}-\rho_{0}(\ddot{\boldsymbol{x}}+\Delta \ddot{\boldsymbol{x}})\right\} \cdot \delta \boldsymbol{x} d V_{0} \\
& =\int_{V_{0}}(\boldsymbol{\Pi}+\Delta \boldsymbol{\Pi}): \delta \boldsymbol{T} d V_{0}
\end{aligned}
$$

式 (35)，(36）中の $\delta \boldsymbol{x}, \boldsymbol{\delta} \boldsymbol{T}$ は任意であるから, $\Delta t$ 後までに実際に生じた増分 $\Delta x, \Delta T$ についても 成立しなければならない， $\delta \boldsymbol{x}, \delta \boldsymbol{T}$ をこれらの増分 に置き換えて式（35），(36）を辺々引くと次式を 得る.

$$
\begin{aligned}
\int_{S_{0}} \Delta t_{0} \cdot \Delta x d S_{0}-\int_{V_{0}} \Delta \Pi: \Delta T d V_{0} \\
=\int_{V_{0}} \rho_{0} \Delta \ddot{x} \cdot \Delta x d V_{0}
\end{aligned}
$$

ところで，上式において $\Delta \boldsymbol{T}$ が剛体回転のみの場 合, 変形は生じないことから, $\Delta \Pi=0, \Delta t_{0}=0$ で あり, 応力の平衡条件は静的に満たされ, 加速度運 動は生じないことになる. 以下の議論においてはこ

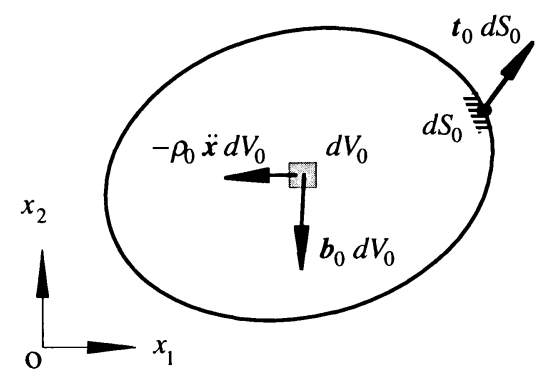

図-5 領域に作用する外力の基準状態における表示

のような特殊な状態は除外しておくこととする.

本文においては安定性を以下のように考える。静 的平衡条件を満たす系に一時的外乱を与えたとき， その後の系の運動が周期的である場合, 系は復元性 を有する。逆に, 周期性のない運動が生じる場合, もし粘性滅衰が零であれば, 系は復元不可能である. 一方，粘性減衰があれば系は復元することもあり得 るが，本文では材料として砂のような材料を対象と し, 粘性隇衰は十分小さいと仮定する。このとき, 周期性がなければ，事実上系は復元せず，不安定で あるとみなすことができる，後に示すように，非周 期的運動の場合, 式 (37) 右辺の符号は必ず正とな り，これより安定条件式を誘導することができる。 ここではこのような考え方に基づい定式化を行う.

以下の議論に拉いては, 前提条件として, 領域内 で急激な構造変化が生ぜず, 諸量の変化が十分滑ら かに生じるとする.さらに，このことから，領域内 の全物質点の運動は十分小さな時間間隔 $\Delta t$ に対し て次式のような变数分離形により表すことができる と仮定する。

$\boldsymbol{x}(X, t+\tau)=\boldsymbol{x}(X, t)+\chi(X, t) g(\tau) \quad(0 \leq \tau \leq \Delta t)$

このとき式 (37) の右辺は以下のように変形される.

$$
\int_{V_{0}} \rho_{0} \Delta \ddot{\boldsymbol{x}} \cdot \Delta \boldsymbol{x} d V_{0}=\Delta g \Delta \ddot{g} \int_{V_{0}} \rho_{0} \boldsymbol{x} \cdot \boldsymbol{x} d V_{0}
$$

いま， $\tau=0$ において系はある平衡状態にあり， 系内の物質点は $\boldsymbol{x}(\boldsymbol{X}, t)$ に置かれ, $g(0)=0$ とする。 また，時刻 $t$ における外乱として， $g(\tau)$ に対する初 速度が $\dot{g}(0)$, 変形モードが $\chi(X, t)$ となる運動が与 えられたとする。このとき, 物体力は一定であると する.ささらに, 系の動的平衡条件式の具体的な形が, 通常の運動方程式に扔けるように，時間に関して 2 階の微分方程式であるとし, 構成則を考慮した後の 動的平衡条件式を次のように置く.

$$
\rho_{11} \chi \ddot{g}+D_{1} \chi \dot{g}+D_{2} \chi g=0
$$

ここに, $D_{1}, D_{2}$ は構成則により定まる空間的な微 分演算子である.いま, この式と $\chi$ との内積をとっ 
て領域 $V_{0}$ で積分すれば, 次式を得る.

$$
M \ddot{g}+C \dot{g}+K g=0
$$

ここに,

$$
M=\int_{V_{0}} \rho_{0} \chi \cdot \chi d V_{0}, C=\int_{V_{0}} \chi \cdot D_{1} \chi d V_{0}, K=\int_{V_{0}} \chi \cdot D_{2} \chi d V_{0}
$$

は, それぞれ, 質量, 粘性隇衰, 剛性に対応した量 である.ここで, 次のパラメータを定義しておく.

$$
\alpha=\left(\frac{C}{2 M}\right)^{2}-\frac{K}{M}
$$

式（41）の解は以下のように与えられる.

a. $\alpha>0$ のとき

$$
g(\tau)=\frac{\dot{g}(0)}{2 \sqrt{\alpha}} e^{-\frac{c}{2 M} \tau}\left(e^{\sqrt{\alpha} \tau}-e^{-\sqrt{\alpha} \tau}\right)
$$

b. $\alpha=0$ のとき

$$
g(\tau)=\dot{g}(0) \tau e^{-\frac{c}{2 M} \tau}
$$

c. $\alpha<0$ のき

$$
g(\tau)=\frac{\dot{g}(0)}{\sqrt{-\alpha}} e^{-\frac{c}{2 M} \tau} \sin \sqrt{-\alpha} \tau
$$

系の粘性減衰が小さい場合, これらの解の中の a. および b. の挙動は外乱に対して事実上 $\tau=0$ の状態 に戻らないので不安定とみなす。これに対して，c. は周期運動であり, 復元性があるので, 安定とみな す. 上式およびその 2 階微分式に含まれる関数を, $\tau=0$ の近傍で $\tau$ の 1 次項までを含むテーラー展開 で近似すると, 全ての場合について, 次式を得る.

$$
\Delta g \Delta \ddot{g} \approx(\dot{g}(0))^{2}\left\{\left(\frac{C}{M}\right)^{2}-\frac{K}{M}\right\} \Delta t^{2}
$$

a. および b. の場合上式の右辺は正である。 また, c. の場合, 粘性隇衰が剛性に比して小さく, 少なく とも $\frac{K}{M}>\left(\frac{C}{M}\right)^{2}$ が成立するとき, 上式の右辺は負と なる．逆に $\Delta g \Delta \ddot{g}<0$ が成立するのは c. の場合に限 られる.ただし, 周期性の解は $\left(\frac{C}{M}\right)^{2} \geq \frac{K}{M}>\left(\frac{C}{2 M}\right)^{2}$ の場合も存在することに注意する必要がある。よっ て, $\Delta g \Delta \ddot{g}<0$ は系が安定であるための十分条件を 与え, 次式と等価である.

$$
\int_{V_{0}} \Delta \boldsymbol{\Pi}: \Delta \boldsymbol{T} d V_{0}>\int_{S_{0}} \Delta t_{0} \cdot \Delta \boldsymbol{x} d S_{0}
$$

とくに，境界条件が変位拘束 $(\Delta x=0)$ と死荷 重 $\left(\Delta t_{0}=0\right)$ の組み合わせで与えられ, 強制的外 力の作用がない状態で不安定性が生じない条件とし て, Hill の安定条件

$$
\int_{V_{0}} \Delta \Pi: \Delta T d V_{0}>0
$$

を誘導することができる，すなわち， 2 次の仕事増
分の積分值が正という条件が得られる。このよう に, Hill の安定条件は式（45）で表される不等式に おいて右辺を零と置いた特殊な場合として誘導され ることが注目される。

なお，上記のように，周期性の解は $\Delta g \Delta \ddot{g}>0$ の 場合にも生じ得るので, 式（45）や式（46）は系が 安定であるための十分条件と考えるべきである，た だし, 式（41）の中の係数 $C$ が零, すなわち粘性隇 衰がない場合には, 式（45）や式（46）は系が安定 であるための必要十分条件となる。このとき，安定 条件は係数 $K$ が正となる条件に等価である.

運動特性を決定する微分方程式（41）の各係数 $M, C, K$ は変形モード $\chi$ に依存した量であるが，も し, 対象とする構成則のもつ特性として, 常に式 （45）や式（46）が保証されれば, 式（37）より, 実現可能なあらゆる変形モード $\chi$ に対して系は安定 であるということができる。

Hill は，構成則として弾性体や弾塑性体モデルを 具体的に仮定し, 解の唯一性の条件として式 (46)

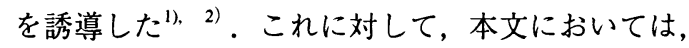
構成則は陽には用いず，解 $\boldsymbol{x}(\boldsymbol{X}, t)$ の示す動的性質か ら逆に系の安定条件として同式の誘導を行った．当 然, 実際に式（46）が成立するかどうかは構成則に 依存している。いま，構成則として線形弾性体モデ ルを考えると, 式 (46) の被積分関数は正值 2 次形 式となり，Hill の安定条件が満たされることは明ら かである.

これまでの説明においては，増分や積分のもつ意 味を明確にするために, 全て有限変形理論の表現を 用いたが，次章も含め，以下の具体的な応用は微小 変形に限定する。

ここで, Hill の安定条件の非関連流動則モデルへ の適用について考える. 応力増分 $\Delta \sigma$ （圧縮を正と する）に対する負荷方向の塑性ひずみ増分テンソル は次式で与えられる。

$$
\Delta \varepsilon_{\mathrm{p}}=(1 / h) m n: \Delta \sigma
$$

ここに, $\boldsymbol{m}$ は塑性ひずみ増分の方向を表す単位のテ ンソル $(\boldsymbol{m}: \boldsymbol{m}=1), \boldsymbol{n}$ は降伏曲面の外向き法線を 表す単位のテンソル $(\boldsymbol{n}: \boldsymbol{n}=1), h$ は硬化状態によ り定まる正值スカラー量である。式（47）より2次 の塑性仕事増分は次式で与えられる.

$$
\Delta \sigma: \Delta \varepsilon_{\mathrm{p}}=(\boldsymbol{m}: \Delta \boldsymbol{\sigma})(\boldsymbol{n}: \Delta \boldsymbol{\sigma}) / h
$$

塑性ひずみが生じる条件は $n: \Delta \sigma>0$ であるので, 2 次の塑性仕事増分の正負は $\boldsymbol{m}: \Delta \sigma$ の正負によって 定まる.いま, Druckerの安定条件) が満たされ， 2 次の塑性仕事増分が正であれば， 2 次の弾性仕事増 分 $\Delta \sigma: \Delta \varepsilon_{\mathrm{c}}\left(\Delta \varepsilon_{\mathrm{c}}\right.$ は弾性ひずみ増分）は常に正であ 


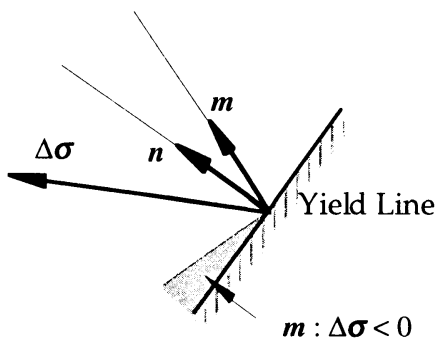

図-6 非関連流動則における不安定領域

るから， 2 次の仕事増分 $\Delta \boldsymbol{\sigma}: \Delta \boldsymbol{\varepsilon}$ （ $\Delta \boldsymbol{\varepsilon}$ は全ひずみ増 分）は正となり, Hill の安定条件は必然的に満たさ れる，ところで, 非関連流動則においては $\boldsymbol{m} \neq \boldsymbol{n}$ で あることから，図-6 に示すように， $\boldsymbol{m}: \Delta \boldsymbol{\sigma}<0$ とな る方向が必ず存在する。一様な応力を受ける供試体 においては，このような載荷に対して Hill の安定条 件が満たされる保証がないことになる ${ }^{3)}$ (4).このこと は非関連流動則モデルに備わった宿命であるという ことができる.

以下，ある増分載荷に対して式（46）左辺の被積 分関数が正，すなわち，

$$
\Delta \sigma: \Delta \varepsilon>0
$$

が成立する場 合に系は安定であるという十分条件の 下に安定性の検討を行う。いま静的な平衡状態にあ る系に増分載荷を行った結果，安定的に変形が生じ 再び静的な平衡状態が得られたとすると，式（37） の右辺は零, したがって，

$$
\int_{V} \Delta \boldsymbol{\sigma}: \Delta \varepsilon d V=\int_{S} \Delta t \cdot \Delta \boldsymbol{x} d S \text { (静的な場合) }
$$

が得られる。ここに， $V, S$ は現在の体積領域とその 境界面， $\boldsymbol{t}$ は現在の境界面の単位面積当たりの表面 力である. Lade ${ }^{3)}$ の行ったような実験的研究におい ては，供試体内部の応力分布を実際に調べることが できないので，供試体外部の計測值を基に式（50） の右辺に相当する量を求め，間接的に式（46）また は一様応力分布を仮定した式（49）が成立するかと うかを調べることになる，本研究においても同様の 方法をとることとする。シミュレーションに扮ける 応力は境界粒子に作用する接触力を基に定義される 平均値であり，式（13）や式（15）を参照すれば, 式 (50) の右辺は平均応力増分と変形勾配増分の積 に領域の体積（2 次元解析の場合は面積）を乗じた ものに等価であることがわかる，そこで，種々の増 分載荷（応力プローブ）を与えて，この式をもとに 2 次の仕事増分の積分值を求め, 式 (49) が平均的 に成立するかどうかを調べることとする.

式（46）の誘導においては, 領域内の運動が時刻 $t$ から $t+\Delta t$ の間で滑らかであり, 運動が変数分離

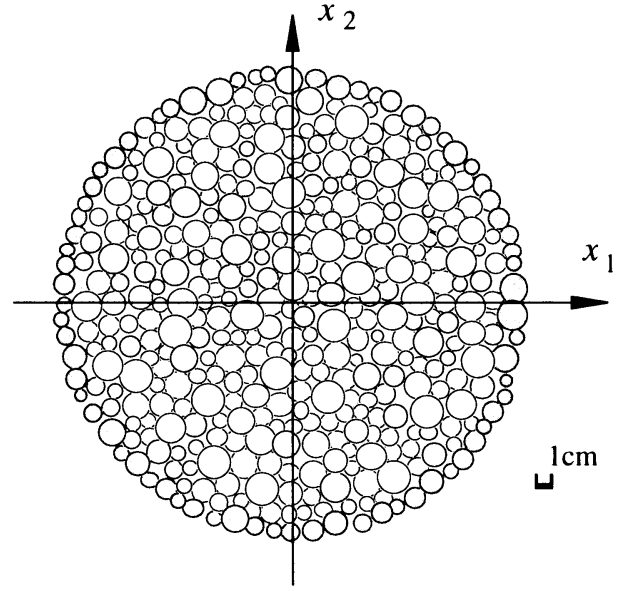

図-7 用いた粒状供試体モデル

できるという前提条件を仮定した。したがってここ のような誘導方法を Hill の安定条件式の妥当性の根 拠とするならば，粒状体において，その内部構造が 急激に変化するような場合には, Hill の安定条件は 適用できないことになる。さらに，たとえば塑性論 においては載荷方向と除荷方向で応力ひずみ関係が 異なるが，一般的な安定性評価を行うためには，種々 のプローブ方向毎に線形比較体として検討する必要 がある。一般に運動の方向毎に安定性評価を行う必 要性があることは, 式（41）以下の条件式の誘導過 程を見ても明らかである，構成則が運動方向によっ て異なると，たとえば，周期運動の応力反転に対し て，変数分離型の関数表現ができない。しかし，実 際の適用に当たっては, 最初に与える運動方向の構 成関係に基づく運動が復元困難なものであるか否か ということで安定性の評価を行うことができよう.

\section{4. シミュレーションによるHillの安定条件の検討}

ここでは，図-7に示すような粒状供試体モデルに ついて行った要素試験シミュレーションの試験結果 に基づいてHillの安定条件の検討を行う.シミュレー ションに用いた粒状供試体モデルは，395 個の円形 粒子（内72個は境界粒子）を充填したものである。 粒子半径は $0.5 \mathrm{~cm}$ から $1 \mathrm{~cm}$ までの一様乱数分布に従っ て選んだ。粒子間接触点における法線および接線方 向のバネ定数を，それぞれ，1000 kN/m および 700 $\mathrm{kN} / \mathrm{m}$ ，粒子間摩擦角を $25^{\circ}$ とした。また粒子間粘 着力は零とした。全ての要素試験シミュレーション は $x_{1}, x_{2}$ 方向を応力主軸とする主軸回転のない応力 制御により行った。要素試験シミュレーションは側 


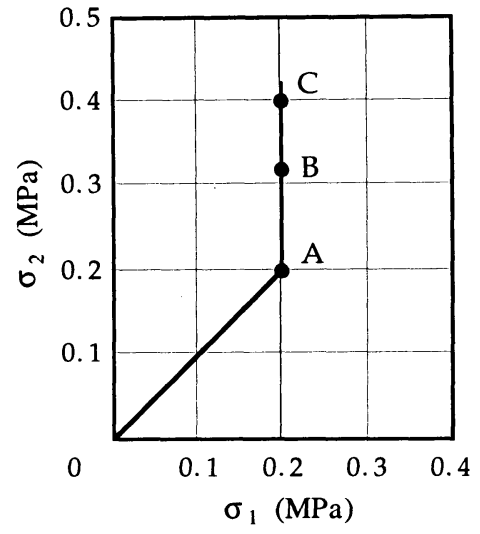

図-8 シミュレーション載荷経路

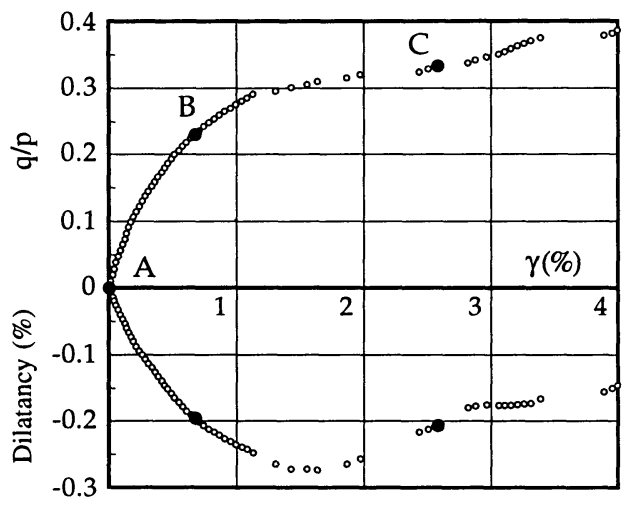

図-9 応力ひずみ関係

圧一定せん断載荷試験と, この試験より得られる中 途データから分岐して行う詳細な応力プローブ試験 とからなる。

まず，前者については既に発表しているので)， 解析結果は応力ひずみ関係のみを記す．側圧一定せ ん断載荷試験シミュレーションは，図-8に示すよう に, 等方圧 $0.2 \mathrm{MPa}$ の 点まで等方載荷した後に行っ た. 軸応力の増分は $\Delta \sigma_{2}=8 \mathrm{kPa}$ とした. 図-9 に応力 ひずみ関係を示す．同図の応力比は主応力を用いて，

$$
q / p=\left(\sigma_{2}-\sigma_{1}\right) /\left(\sigma_{1}+\sigma_{2}\right)
$$

と表される量であり，横軸は最大せん断ひずみ

$$
\gamma=\sqrt{\left(\varepsilon_{11}-\varepsilon_{22}\right)^{2}+4 \varepsilon_{12}^{2}}
$$

である. 図にはシミュレーション解析における各載 荷ステップ終端の状態を。印でプロットした．応力 比の大きな部分でこれらのプロットの間隔が大きな 部分があるが，このような載荷ステップは一定の応 力增分に対する応答がやや不安定であることを示し ている．またダイレイタンシー $-\left(\varepsilon_{11}+\varepsilon_{22}\right)$ の変化よ り, 用いている粒状供試体モデルはやや緩詰めのも
のであるということができよう.

つぎに，Hill の安定条件の検討を行うために実施 した詳細な応カプローブ試験の結果とその考察につ いて示す。詳細な応力プローブ試験は, 図-8, 9 に示 したせん断載荷試験について, 載荷途上の B,C 2 点 において実施した。この 2 点の中， B 点は硬化過程 にあり変形は安定的に生じると考えられる。また， $\mathrm{C}$ 点は比較的大きな変形が生じる点である，応力増 分の絶対值は $|\Delta \sigma|=1 \mathrm{kPa}$ とした. 一方, プローブ 方向は主応力空間上で $9^{\circ}$ 毎の 40 方向とし, 各々の 方向に載荷・除荷を行った。これらの応力プローブ 試験により，各プローブ方向の塑性ひずみ増分，お よび 2 次の塑性仕事増分と全仕事増分を求めた。 以 下に解析結果とその考察を示す。なお, Bard et ${ }^{5)}$ も 個別要素法を用いた応力プローブ試験により弾塑性 挙動の検討を行っているが, プローブ方向は 8 方向 と限定されたものであり，また，応力制御が十分な 精度で行われていないために，以下に示すような詳 細な検討を行うまでには至っていない.

図-10は B 点各プローブ方向の塑性ひずみ増分の 絶対值を極座標上にプロットしたものである．同図 の角度は主応力空間におけるプローブ方向の $\sigma_{1}$ 軸 からの角度を表す。この図に示したように，塑性ひ ずみ増分の絶対值を連ねた線は円状となり，これを もとに，塑性ひずみが生じる方向と生じない方向の 境界線，すなわち降伏曲線の接線を定めることが可 能である．同図にはこの降伏曲線の接線と降伏曲線 の外向き法線を表す単位のテンソル $\boldsymbol{n}$ を示した。こ のような降伏曲線の接線の決定方法は細かな応力プ ローブ試験を実施してはじめて可能となるものであ る。また, Bardet ${ }^{5)}$ の解析とは異なり，剛性行列に 基づく正確な応力制御が行われたため，このような 方法を用いることができたということができる．

図-11 は B 点各プローブ方向の塑性ひずみ増分の 主ひずみ空間におけるプロットを示す，同図に記さ れている角度は $\Delta \varepsilon_{1}^{\mathrm{p}}$ 軸からの角度を表す。ひずみ空 間における各プローブ方向の塑性ひずみ増分べクト ルは応力増分の方向に拘わらずほぼ一定の方向 $\boldsymbol{m}$ を向いており，近似的に塑性論における仮定が成立 しているとみなすことも不可能ではない.

以上，主応力空間における $n$ の方向，および主ひ ずみ空間における $\boldsymbol{m}$ の方向を定めることが可能で あることを示したが，応力主軸と塑性ひずみ増分主 軸の方向には若干ではあるがずれが認められる。す なわち，本文におけるせん断載荷試験や応力プロー ブ試験はすべて主軸回転を伴わない応力制御で行っ ているので, 応力主軸の方向は固定されていて常に $\sigma_{12}=0$ であるが，ひずみについては対称性以外の拘 


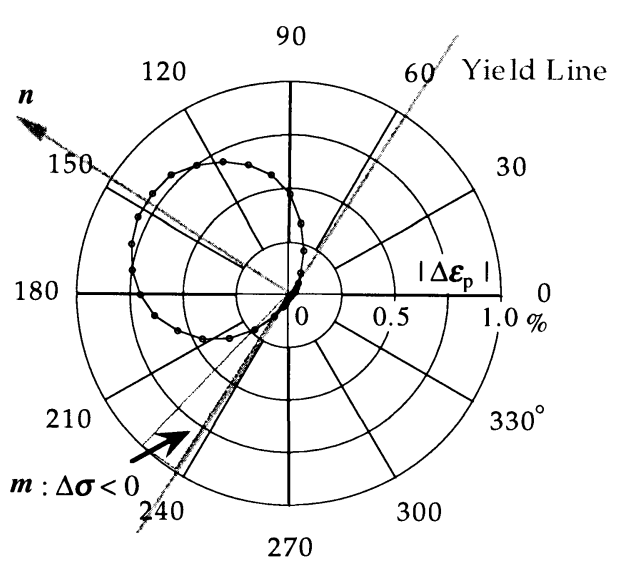

図-10 各プローブ方向の塑性ひずみ増分の絶対值（B 点）

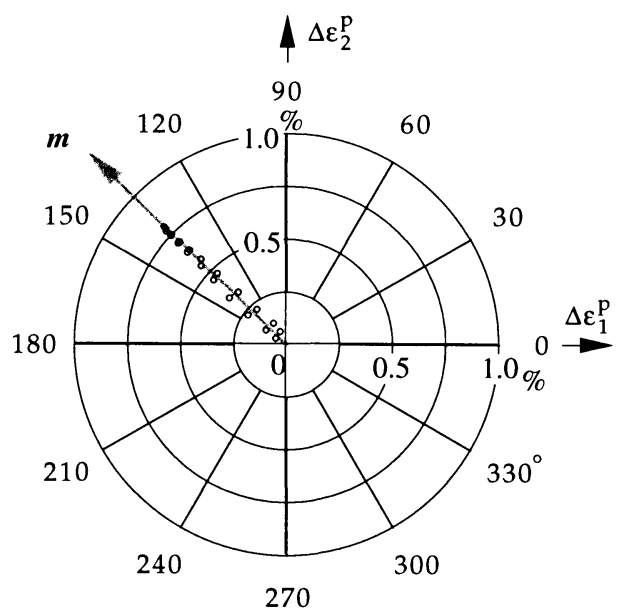

図-11 塑性ひずみ増分の塑性主ひずみ空間表示（B 点）

束はないので一般に $\varepsilon_{12} \neq 0$ であり，ひずみ主軸は回 転可能である. 実際, B 点での応力プローブ試験に おける塑性ひずみ増分の主軸の方向は, プローブ方 向によって若干異なるが, 応力主軸の方向から右ま わりに $4.5^{\circ}$ 前後であった. ただし，この差が流動則 の検討に及ぼす影響はクリティカルなのものではな く, $\boldsymbol{m}$ の主值を近似的に $m_{1}=m_{11}, m_{2}=m_{22}$ と置く ことに含まれる誤差, すなわち, $\left|\left(m_{11}-m_{1}\right) / m_{1}\right|$ や $\mathrm{I}\left(m_{22}-m_{2}\right) / m_{2} \mid$ の值は $1 \%$ 程度であった.

得られた降伏曲線の外向き法線方向 $\boldsymbol{n}$ と平均的塑 性ひずみ増分方向 $\boldsymbol{m}$ とを比較すると, $\boldsymbol{m} \neq \boldsymbol{n}$ であり, 流動則については少なくとも関連流動則が成立する とみなすことはできず, 大局的には非関連流動則に 従うとみなすべきである。しかし，この場合, 図-10 に示したグレー色の部分で $\boldsymbol{m}: \Delta \boldsymbol{\sigma}$ は負となり, Hill の安定条件が満たされないことになる。ここで, 応 カプローブ試験結果をさらに詳細に調べ, 流動則の

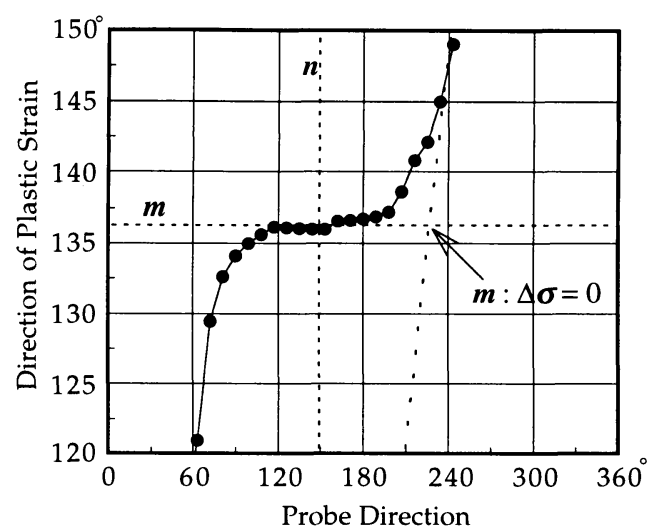

図-12 塑性ひずみ増分ベクトルの方向（B 点）

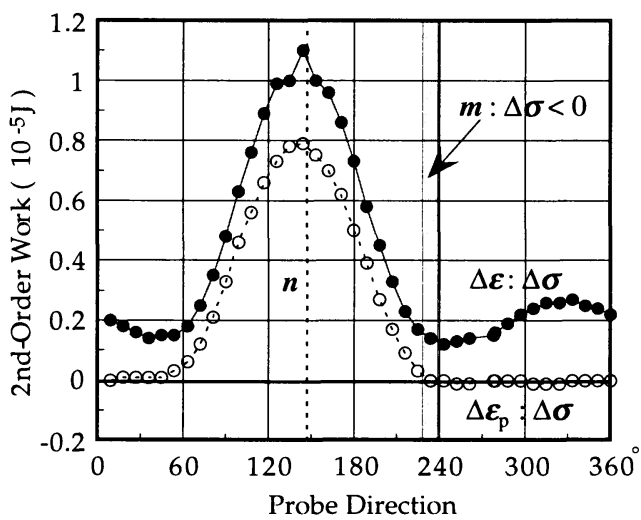

図-13 各プローブ方向の 2 次の仕事増分 (B 点)

再吟味を行うこととする.

図-12 はプローブ方向による塑性ひずみ増分の方 向の変化を示したものであるが, 明らかに, 塑性ひ ずみ増分の方向について一定方向 $\boldsymbol{m}$ からのずれが 観察され, 塑性ひずみ増分の方向が負荷方向に依ら ず一定という塑性論に抒ける仮定が成り立っていな い.このようなずれは図-10 と対比すると, 塑性ひ ずみレベルの小さな部分で生じていることがわかる.

図-12には，2次の塑性仕事増分が正から負に変 わる限界線（塑性ひずみ増分の生じる方向がプロー ブ載荷方向と直角をなす線）を示した。もし，塑性 ひずみ増分の方向が一定值 $\boldsymbol{m}$ で与えられるとする と, 同図の矢印で示した箇所より右で 2 次の塑性仕 事増分が負となる. しかし, シミュレーションでは, 塑性ひずみ増分の方向が一定にはならず, 全ての負 荷プローブ方向で 2 次の塑性仕事増分がほほ正とな るように変化が生じていることが注目される，実際 に各プローブ方向の塑性仕事増分および全仕事増分 を算定してみると 図-13 のようになる。塑性仕事増 分による 2 次の仕事増分はほぼ常に正で, Drucker の 


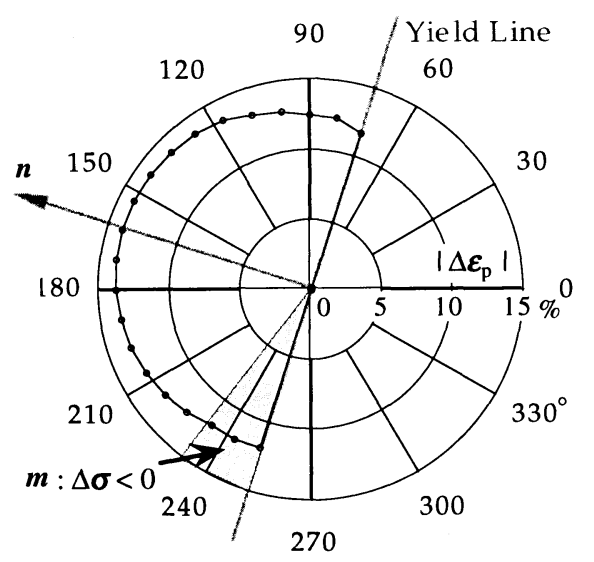

図-14 各プローブ方向の塑性ひずみ増分の絶対値（C 点）

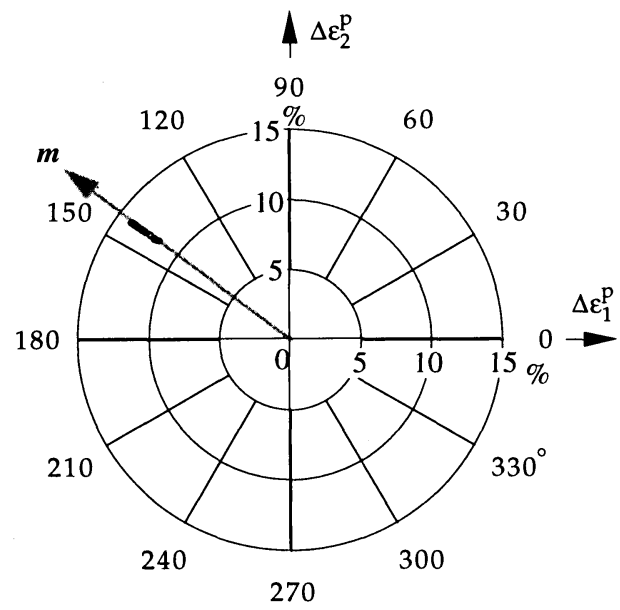

図-15 塑性ひずみ増分の主ひずみ空間表示（C 点）

安定条件 ${ }^{4)}$ が満たされており，したがってこれに弾 性部分を加えた全ひずみ増分の 2 次の仕事増分は完 全に正となり，Hill の安定条件が満たされることが わかる。このように，非関連流動則からのずれが Hill の安定条件を満たすように生じることは非常に 注目すべきことである。

つぎに，大きな変形を生じた C 点について同様 の応力プローブ試験を行った結果を示す. 図-14,15 に，それぞれ，各プローブ方向の塑性ひずみ増分の 絶対值，および主ひずみ空間上にプロットした塑性 ひずみ増分を示す， B 点の場合と比較して，塑性ひ ずみ増分の大きさは, 同じ大きさの応力増分に対し 約 20 倍と非常に大きな值となった. 載荷試験は応力 制御で行っているために，一時的に軟化状態になっ た可能性もあり得る。また， B 点の場合と異なり，

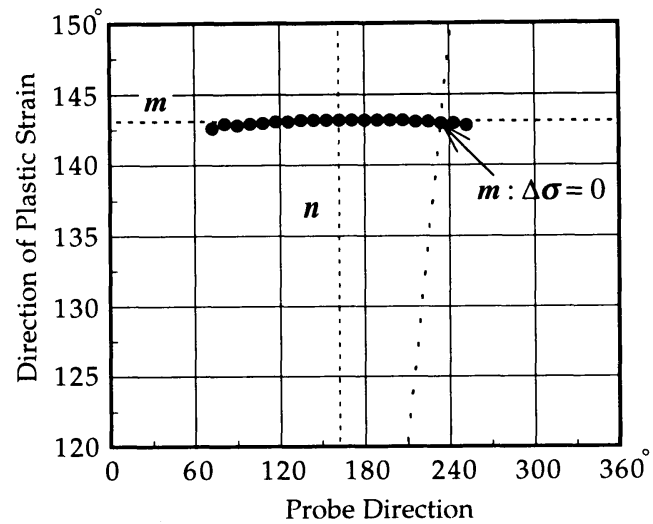

図-16 塑性ひずみ増分ベクトルの方向（C 点）

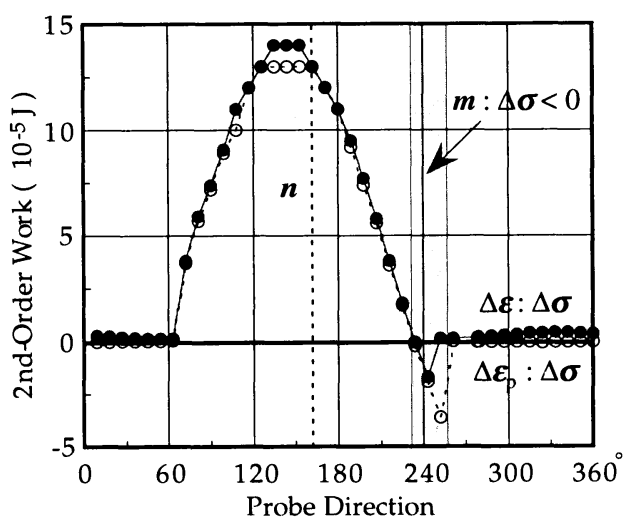

図-17 各プローブ方向の 2 次の仕事増分（C 点）

塑性論における塑性ひずみ増分の方向が負荷方向に 依らず一定という仮定自体はほほ成立している。し かし，ひずみ增分の大きさについては，各プローブ 方向とも一様に大きな值となり, 式 (47) の非関連 流動則から大きくずれている．なお， C 点の応力プ ローブ試験における応力主軸と塑性ひずみ増分主軸 の方向の差は約 $8^{\circ}$ と $\mathrm{B}$ 点の場合より大であった.

図-16に各プローブ方向の塑性ひずみ増分の方向 を示す．図-12の場合とは異なり, 塑性ひずみ増分の 方向は負荷方向に依らず一定という傾向が現れてい る.この理由は, 応力レベルが高くなるにつれて粒 状供試体内部においてすべりのメカニズムに支配さ れた特定の固有変形モードが形成され易いためと考 えられる ${ }^{11)}$.もし，塑性ひずみ増分の方向が一定で あれば，図-16の斜めの破線の右側で 2 次の仕事増 分は負になる。実際に各プローブ方向の 2 次の仕事 増分の值を示せば, 図-17のようになり, Hill の安定 条件が満たされない場合が生じることがわかる。し かし, 各方向ともひずみ増分の程度は同程度であり, 
とくに Hill の安定条件が満たされない方向で特異と なる現象は見られない. 以上のような力学特性を示 す C 点においては, 3. で安定条件の誘導の際に仮定 した変数分離が適用できない可能性が大きい.すな わち, 粒状体のシミュレーション解析過程において は, 内部構造が時々刻々変化し，とくに応力レベル が最大に近づくと, 変化も顕著である。一般に材料 内部の微視構造の変化は解くべき運動方程式系の変 化を意味するので, 3. に示したような連続体理論は C 点のような場合には適用が困難であろう。この C 点では Hill の安定条件が満たされないような応 力増分方向が実際に存在したことから, 剛性はかな り低下しており, 各プローブ方向とも大きな変形が 生じたと考えられる.

一方, B 点は応力レベルが中程度の硬化過程にあ り, 剛性も十分に大きく, 不安定性の存在は想定し 難い。しかし，流動則は関連流動則とはならないの で，一見不安定性が含まれているように思われる.

この矛盾は, 上述のように, 流動則が非関連流動則 から僅かにずれており，この僅かなずれのために Hill の安定条件が満たされると考えることにより解 決された。このようなずれは構成則における増分非 線形性 $^{12)}$ を示唆するものである.

従来より非関連流動則と安定性の関係については 種々の議論がなされてきた. Lade は砂の排水実験結 果より非関連流動則は成立するが Hill の安定条件, さらには, Drucker の安定条件は実験結果の安定性評 価に用いることができないと結論づけだ)。また,

Druckerは非関連流動則が成立する場合には必ず不 安定性が生じ得るので敢えて非関連流動則を用いる ことには問題があると述べだ)。これらの議論はい ずれも古典的流動則を前提としたものであるが, 本 研究におけるシミュレーション解析結果から判断す る限り，B点およびC 点のいずれにおいても厳密に は流動則が成立しない. LadeとDruckerの議論の中, 実験によると塑性ひずみ増分応答は関連流動則に適 合しないという Lade の主張や, 非関連流動則なら ば不安定な変形が生じるという Drucker の主張は正 しいであろう. しかし，地盤材料の挙動が古典的な 流動則に忠実に適合するものであるということが実 際の実験で検証されない限り, 流動則を前提とした 議論から正しい結論を導くことはできないであろう。 本研究のシミュレーション試験結果は, 古典的流動 則を前提とした両者の議論の原点に問題があること を示唆するものである.

以上のように，非関連流動則に基づく Hill の安定 性評価が現実に合わないという問題は, 式 (47) で 与えられる流動則の現実とのずれを考慮することに
より説明が可能となった，また, Hill の安定条件を 適用するためには，3.に述べた前提条件を満たして おくことにも注意する必要がある。このように，地 盤材料の安定性評価においては, 非関連流動則のも つ欠点の問題と, 構造変化による不均一性の発達の 問題とが混在することになるので, これらを明確に 分離して議論を行う必要があろう.

粒状体の挙動を表現する構成則を設定する上で, 安定性を確実に確保するためには, 本シミュレーショ ン解析の B 点に見られるような増分非線形性を考慮 寸る必要があるであろう。何らかの増分非線形性を 考慮した具体的なモデルも既に種々提案 ${ }^{13)}$ ，14，15) が なされているが, 実際の挙動を精度良く表現し, 物 理的に意味のある定式化を行うことが必要となるで あろう。また, 応カレベルが高い領域では, 解析上 変数分離ができない状態があり得,このような場合 には不均一性の発展をとり入れるための特別な工夫 も必要になると考えられる。

\section{5. 結 語}

本研究は, Hill の安定条件が粒状体の安定性評価 に適用できるか，また，適用できるとすれば，非関 連流動則を用いたときの矛盾がどのように是正され るかを調べる目的で行われたものである。この検討 を進めるために，まず，粒状要素法による要素試験 シミュレーションを実施するとともに, Hill の安定 条件の意味を明らかにするための考察を行った。本 文においては, 以下に示す諸項目の詳細を示した。

1 ) 粒状体の非弾性挙動に関する基本データを得る ための応力制御要素試験シミュレーションのアルゴ リズムの提示

2 ) 動的仮想仕事の原理に基づく安定条件式の誘導, および, 安定性の考え方や安定性評価を行う上での 制約事項の提示

3 ) 側圧一定せん断載荷シミュレーションの 2 種の 中途データに対して行った詳細な応力プローブ試験 シミュレーションの結果とその考察の提示

本文にも述べたように, 粒状要素法は, 個別要素 法と異なり，剛性関係式に基づくアルゴリズムを用 いているため応力制御が十分な精度で行われ，本研 究における詳細な考察を可能とした. Bardet ${ }^{5)}$ も従 来の弾塑性理論では表せない現象の把握を目的とし て個別要素法に基づく検討を行ったが, 弾塑性理論 以外の構成則理論を用いなければならない根拠を見 出すことはできなかったと述べているに留まってい る.このことから，1）に示したアルゴリズムは今 
後とも, 粒状体の合理的な構成則を検討する上で有 用であろう。

Hill は静的な仮想仕事の原理に基づき, 材料の構 成則として弾性や弾塑性を仮定した上で解の唯一性 の条件として安定条件式を導いた。これに対して2）

に示した条件式の誘導は動的な仮想仕事の原理に基 づき, 外乱を与えた後の運動のもつ特性から安定性 を定義し，十分条件式としての安定条件式を導いた。

とくに特定の構成則に限定した誘導ではない点が Hill の誘導よりは一般的であると思われる。ただし， この式を導くに当たって, 運動方程式の解の変数分 離可能性を前提とした。この前提は安定性評価の適 用を制限するものであるが, 実際の粒状材料で内部 構造が大きく変化する場合までを含めた安定性評価 を行うことは本来困難である。本文に示した前提条 件の下における安定性評価はこのような段階に達す る以前の安定性評価として位置付けられよう。

3 ）の粒状要素法を用いて実施した応力プローブ 試験シミュレーション結果において最も注目される のは, 安定な硬化状態においては塑性ひずみ増分の 方向が一定方向に生じるという古典的流動則の仮定 が厳密には満たされなかったことである。しかも， そのずれは，非関連流動則を用いた場合に Hill の安 定条件が満たされないという不都合を解消するもの である。このような結果は本研究における詳細な応 カプローブ試験シミュレーションではじめて得られ た知見であると思われる。 また，この結果は粒状材 料の構成則に必要に応じて増分非線形性を持ち込ま なければならないことを示唆するものである.

謝辞：本論文をとりまとめるに当たり，東北学院大 学工学部の飛田善雄教授, 東北大学大学院工学研究 科の岩熊哲夫教授・新関 茂助教授・京谷孝史助教 授にいろいろと御討議を頂いた。ここに記して謝意 を表します。

\section{参考文献}

1) Hill, R.: On uniqueness and stability in the theory of finite elastic strain, J. Mech. Phys. Solids, Vol.5, pp.229-241, 1957.

2) Hill, R. : A general theory of uniqueness and stability in elastic-plastic solids, J. Mech. Phys. Solids, Vol.6, pp.236-249, 1958.

3) Lade, P.V. and Pradel, D.: Instability and plastic flow of soils. I: Experimental observations, J. Engrg Mech., ASCE, Vol.116, pp.2532-2550, 1990.

4) Drucker, D.C. and $\mathrm{Li}, \mathrm{M}$.: Triaxial test instability of a nonassociated flow-rule model, J. Engrg Mech., ASCE, Vol.119, pp.1188-1204, 1993.

5) Bardet, J.P.: Numerical simulations of the incremental responses of idealized granular materials, Int. J. Plasticity, Vol.10, pp.879-908, 1994.

6) Cundall, P.A. and Strack, O.D.L.: A discrete numerical model for granular assemblies, Géotechnique, Vol.29, pp.47-65, 1979.

7) 岸野佑次: 新しいシミュレーション法を用いた粒状体 の準静的挙動の解析, 土木学会論文集, No.406/III-11, pp.97-106, 1989.

8) 岸野佑次, 森谷直樹：粒状体の応力ひずみ関係におけ る増分非線形性の微視力学的解析, 構造工学論文集, Vol.42A, pp.307-316, 1996.

9) 武 建勲, 岸野佑次, 京谷孝史 : 改良粒状要素法による 粒状体の弾塑性挙動の研究, 構造工学論文集, Vol.43A, pp.403-412, 1997.

10) 武 建勲, 岸野佑次, 京谷孝史 : 2 次元粒状体モデルプ ローブ試験による弾塑性挙動の考察, 構造工学論文集, Vol.44A, pp.399-408, 1998.

11) 岸野佑次 : 粒状体の固有変形解析, 土木学会論文集, No.481/III-25, pp.87-95, 1993.

12) Tobita, Y.: Importance of incremental nonlinearity in the deformation of granular materials, IUTAM Symposium on Granular Materials, Fleck, N.A. and Cocks, A.C.F. eds., Kluwer Academic Pub., pp.139-150, 1997.

13) Kolymbas, D.: An outline of hypoplasticity, Archive of Applied Mechanics, Vol.61, pp.143-151, 1991.

14) Darve, F., Flavigny, E. and Meghachou, M.: Yield surfaces and principle of superposition: Revisit through incrementally non-linear constitutive relations, Int. J. Plasticity, Vol.11, pp.927-948, 1995.

15) Hashiguchi, K.: The extended flow rule in plasticity, Int. J. Plasticity, Vol.13, pp.37-58, 1997.

(1998. 5.18 受付）

\title{
APPLICABILITY OF THE HILL'S CONDITION OF STABILITY TO GRANULAR MATERIALS
}

\author{
Yuji KISHINO and Jianxun WU
}

\begin{abstract}
This paper discusses applicability of the Hill's condition of stability to granular materials with the aid of numerical simulations performed in terms of the granular element method. It also presents a new version of the granular element method itself before showing results of stress-probe simulations which give detailed behaviors of a specimen model. Results in a stable state show that the non-elastic behavior exhibits incrementally non-linear character which brings deviation from the non-associated flow rule in such a way that the Hill's condition is fulfilled. Other results show that applicability of the Hill's condition is restricted when the heterogeneity is progressing. The latter restriction seems to have its origin among premises appearing in a new derivation of the Hill's condition of stability.
\end{abstract}

